Short communication

\title{
INHIBITION OF IN VITRO GROWTH OF PORCINE ENTEROTOXIGENIC AND SHIGA TOXIN-PRODUCING ESCHERICHIA COLI BY LACTOBACILLUS PLANTARUM STRAINS
}

\author{
CHANGHOON Park ${ }^{1}$, JIWOON Jeong ${ }^{1}$, KYUHYUNG Choi ${ }^{1}$, JAE CHUL Lee ${ }^{2}$, \\ OH SUNG Kwon², SUNG-HOON Kim², CHANHEE Chae ${ }^{1 *}$ \\ ${ }^{1}$ College of Veterinary Medicine, Seoul National University, 1 Gwanak-ro, Gwanak-gu, Seoul 151-742 \\ Republic of Korea; ${ }^{2}$ College of Oriental Medicine, Kyunghee University, 1 Hoegi-dong, Dongdaemun- \\ Gu, 130-701, Seoul, Republic of Korea
}

(Received $2^{\text {nd }}$ February; Accepted $29^{\text {th }}$ April 2015)

\begin{abstract}
The objective of this study was to assess cell-free fermented culture broth of 9 Lactobacillus plantarum strains as antibiotic alternatives for the inhibition of in vitro growth of enterotoxigenic Escherichia coli (ETEC) and Shiga toxin-producing E. coli (STEC) isolated from postweaning pigs with colibacillosis and edema disease in 2014. A total of 10 ETEC and 5 STEC strains isolated from postweaning pigs were tested in antimicrobial susceptibility tests. ETEC and STEC strains used in this study possessed at least one of fimbrial, enterotoxin, and Shiga-toxin genes when tested by polymerase chain reaction. Among 9 L. plantarum strains tested, 3 strains (Lp 2-05, 2-06, and 1-03) showed inhibitory activity of in vitro growth against 10 ETEC strains $(100 \%)$ and 7 strains (Lp 6-13, 3-06, 3-05, 7-01, 2-06, 1-03, and 6-05) showed inhibitory activity of in vitro growth against 5 STEC strains (100\%). Three strains (Lp 3-05, 2-06, and 1-03) showed inhibitory activity of in vitro growth against 10 ETEC (100\%) and 5 STEC (100\%) strains. The results of this study show the inhibitory activity of cellfree fermented culture broth of L. plantarum against ETEC and STEC isolated from postweaning pigs with colibacillosis and edema disease.
\end{abstract}

Key words: Escherichia coli, in vitro growth inhibition, Lactobacillus plantarum

\section{INTRODUCTION}

Enterotoxigenic Escherichia coli (ETEC) and Shiga toxin-producing E. coli (STEC) are a major cause of diarrhea and edema disease and cause serious losses in postweaning pigs. ETEC has 2 types of virulence factors, fimbriae and enterotoxins. The fimbriae enable the ETEC to colonize the small intestine of piglets by mediating adhesion to the microvilli of epithelial cells. Enterotoxins (heat-labile, LT and heat-stable, ST) stimulate secretion of electrolytes and fluids by intestinal epithelial cells, resulting in

Corresponding author: e-mail: swine@snu.ac.kr 
diarrhea and dehydration [1]. Shiga toxin (Stx) produced by STEC causes vascular necrosis in small blood vessels, resulting in edema at specific locations [2-4]. E. coli carrying F4 (K88), F18, and Stx genes are widely prevalent in pigs with colibacillosis and edema disease [5].

Antibiotics have been commonly used to treat colibacillosis and edema disease in pigs. However, overuse of antimicrobials has resulted in an increase of antimicrobial resistance and failure of treatment of these diseases in pigs farms [6,7]. Therefore, special attention has been paid to the use of antibiotics in animals because the development of antibiotic resistant bacteria would produce a real threat to human health [8-10].

In an effort to reduce antibiotic use in animals, the Korean government has attempted to limit antibiotics use in animal husbandry, especially antimicrobials used in human medicine. This program was extended to phase out all antibiotic feed additives beginning in July 2011 (Ministry for Food, Agriculture, Forestry and Fisheries, Subparagraph No. 2010-142). After the ban of antibiotic feed additives was in effect, 857 postweaning pigs were examined at the Department of Veterinary Pathology at the Seoul National University. Out of 857 pigs that were examined during the 2-year period 2012-2013 immediately following the ban, $274(32 \%)$ showed symptoms of colibacillosis and 32 $(3.7 \%)$ exhibited edema disease. This represents a 4 -fold increase in colibacillosis and an 8-fold increase in edema disease compared to the 2-year period 2010-2011, preceding the ban. This suggests the ban of the antibiotic feed additives may have contributed to the increase in the prevalence of the disease which was observed following the ban. Therefore, there is a need to improve the control and treatment of ETEC and STEC infections without the use of antibiotic feed additives. The objective of this study was to determine the ability of cell-free fermented culture broth from several Lactobacillus plantarum strains, as antibiotic alternatives, to inhibit in vitro growth of ETECs and STECs isolated from postweaning pigs with colibacillosis and edema disease.

\section{MATERIALS AND METHODS}

\section{Escherichia coli isolates}

All of the 10 ETEC and 5 STEC isolated from postweaning pigs with colibacillosis or edema disease in 2014 were used for antimicrobial susceptibility tests. ETEC isolates used in this study carry at least one of fimbrial or enterotoxin genes (Table 1) [5,11] while STEC isolates carry a gene expressing Shiga-toxin as determined by polymerase chain reaction (PCR) as previously described [5].

\section{Agar spot test}

A total of $9 \mathrm{~L}$. plantarum strains were isolated from the feces of a healthy commercial pig to determine inhibitory activity of in vitro growth against ETEC and STEC strains. 
A modification of the agar spot test was used for the determination of antimicrobial activity against $E$. coli as previously described [12,13]. Briefly, a mixture of cell-free fermented culture broth of L. plantarum (Genebiotech Co. Ltd., Seoul, Korea) was filtered with a $0.2 \mu \mathrm{m}$ membrane and $2 \mu \mathrm{l}$ of mixture of cell-free fermented culture broth of L. plantarum was spotted on 1.5\% de Man-Rogosa-Sharpe (MRS) agar plates. Plates were dried for 30 minutes at room temperature and overlaid with $10 \mathrm{ml}$ of Tryptic Soy agar $(0.85 \%)$ at $45^{\circ} \mathrm{C}$ seeded with $1 \%(\mathrm{v} / \mathrm{v})$ of an overnight culture of $E$. coli to obtain a final concentration of $10^{6}$ colony forming units $/ \mathrm{ml}$. Plates were then incubated at $37^{\circ} \mathrm{C}$ and measured for zone of inhibition (clear agar) after 12 hours. Inhibition of in vitro growth test was performed in triplicate on each $L$. plantarum strain against ETEC and STEC. Preparation of agars, dilutions, and inoculations were performed by the same technician for consistency. All plates were set up and read by same technician.

Table 1. Enterotoxigenic Escherichia coli (ETEC) and Shiga toxin-producing E. coli (STEC) strains used in this study

\begin{tabular}{|c|c|c|c|c|c|}
\hline \multirow{3}{*}{$\begin{array}{l}\text { E. coli } \\
\text { strains }\end{array}$} & \multicolumn{4}{|c|}{ Virulence profile } & \multirow{3}{*}{ Shiga toxin } \\
\hline & \multicolumn{2}{|c|}{ Fimbriae } & \multicolumn{2}{|c|}{ Enterotoxin } & \\
\hline & F4(K88) & F18 & Heat-labile & Heat-stable & \\
\hline ETEC-01 & $\mathrm{O}$ & $\mathrm{X}$ & $\mathrm{O}$ & $\mathrm{O}$ & $\mathrm{X}$ \\
\hline ETEC-02 & $\mathrm{O}$ & $\mathrm{X}$ & $\mathrm{X}$ & $\mathrm{O}$ & $\mathrm{X}$ \\
\hline ETEC-03 & $\mathrm{O}$ & $\mathrm{X}$ & $\mathrm{O}$ & $\mathrm{X}$ & $\mathrm{X}$ \\
\hline ETEC-04 & $\mathrm{O}$ & $\mathrm{X}$ & $\mathrm{O}$ & $\mathrm{X}$ & $\mathrm{X}$ \\
\hline ETEC-05 & $\mathrm{O}$ & $\mathrm{X}$ & $\mathrm{O}$ & $\mathrm{X}$ & $\mathrm{X}$ \\
\hline ETEC-06 & $\mathrm{X}$ & $\mathrm{O}$ & $\mathrm{X}$ & $\mathrm{O}$ & $\mathrm{X}$ \\
\hline ETEC-07 & $\mathrm{O}$ & $\mathrm{X}$ & $\mathrm{X}$ & $\mathrm{O}$ & $\mathrm{X}$ \\
\hline ETEC-08 & $\mathrm{O}$ & $\mathrm{X}$ & $\mathrm{O}$ & $\mathrm{X}$ & $\mathrm{X}$ \\
\hline ETEC-09 & $\mathrm{O}$ & $\mathrm{X}$ & $\mathrm{O}$ & $\mathrm{O}$ & $\mathrm{X}$ \\
\hline ETEC-10 & $\mathrm{O}$ & $\mathrm{O}$ & $\mathrm{O}$ & $\mathrm{O}$ & $\mathrm{X}$ \\
\hline STEC-01 & $\mathrm{X}$ & $\mathrm{X}$ & $\mathrm{X}$ & $\mathrm{O}$ & $\mathrm{O}$ \\
\hline STEC-02 & $\mathrm{X}$ & $\mathrm{O}$ & $\mathrm{X}$ & $\mathrm{O}$ & $\mathrm{O}$ \\
\hline STEC-03 & $\mathrm{X}$ & $\mathrm{O}$ & $\mathrm{X}$ & $\mathrm{X}$ & $\mathrm{O}$ \\
\hline STEC-04 & $\mathrm{X}$ & $\mathrm{O}$ & $\mathrm{X}$ & $\mathrm{X}$ & $\mathrm{O}$ \\
\hline STEC-05 & $\mathrm{X}$ & $\mathrm{O}$ & $\mathrm{X}$ & $\mathrm{X}$ & $\mathrm{O}$ \\
\hline
\end{tabular}

\section{Statistical analysis}

Growth data were analyzed using a one-way analysis of variance (ANOVA). If the ANOVA showed a significant effect, Tukey's test for multiple comparisons was performed. A value of $P<0.05$ was considered to be significant. 


\section{RESULTS AND DISCUSSION}

Cell-free fermented culture broth of L. plantarum inhibited in vitro growth of ETEC and STEC. Basal medium that was not incubated with $L$. plantarum was used as the negative control and had no inhibitory effect on ETEC and STEC growth. The zone of inhibition by L. plantarum against ETEC is presented in Table 2. Among 9 L. plantarum strains, 3 strains (Lp 3-05, 2-06, and 1-03) showed inhibitory activity of in vitro growth against all 10 ETEC strains (100\%). One strain (Lp 7-01) showed inhibitory activity of in vitro growth against 9 ETEC strains (90\%). One strain (Lp 6-01) showed inhibitory activity of in vitro growth against 8 ETEC strains (80\%). Strain Lp 3-05 showed a significantly larger $(P<0.05)$ inhibitory zone against all 10 ETEC strains compared to strain Lp 6-05. The zone of inhibition by L. plantarum against STEC is summarized in Table 3. Among 9 L. plantarum strains, 7 strains (Lp 6-13, 3-06, 3-05, 7-01, 2-06, 1-03, and 6-05) showed inhibitory activity against all 5 STEC strains (100\%). Three strains (Lp 3-05, 2-06, and 1-03) showed inhibitory activity all 10 ETEC (100\%) and all 5 STEC $(100 \%)$ strains.

The results of this study demonstrate that $L$. plantarum strains are promising probiotics to control colibacillosis and edema disease in postweaning pigs. These observations are clinically meaningful because outbreaks of colibacillosis and edema disease are rapidly increasing since the restriction of antibiotic feed additives was implemented by the government. An increase of antimicrobial resistance by excessive and improper use of antibiotics is the main cause of failure to effectively treat colibacillosis and edema disease in pig farms [6,7]. The current trend worldwide emphasizes reduction of antibiotic use in animal production in favor of good husbandry practices, and use of antibiotic alternatives and vaccination [14]. Therefore, a cell-free fermented culture broth of $L$. plantarum should be considered as an alternative treatment for the prevention of porcine ETEC and STEC infection. Although antimicrobial activity of L. plantarum has not been fully understood, the antimicrobial activity has been attributed to the production of antimicrobial substances, like oxygen peroxide, organic acids, biosurfactants, and bacteriocins [15].

The present data show the inhibitory activity of cell-free fermented culture broth of $L$. plantarum against ETEC and STEC isolated from postweaning pigs with colibacillosis and edema disease. Interestingly, different L. plantarum strains have different inhibitory activities against ETEC and STEC strains. Despite the fact that in vitro results may not reflect in vivo results, it is necessary to screen and select potential candidate L. plantarum strains for further in vivo antimicrobial studies. 


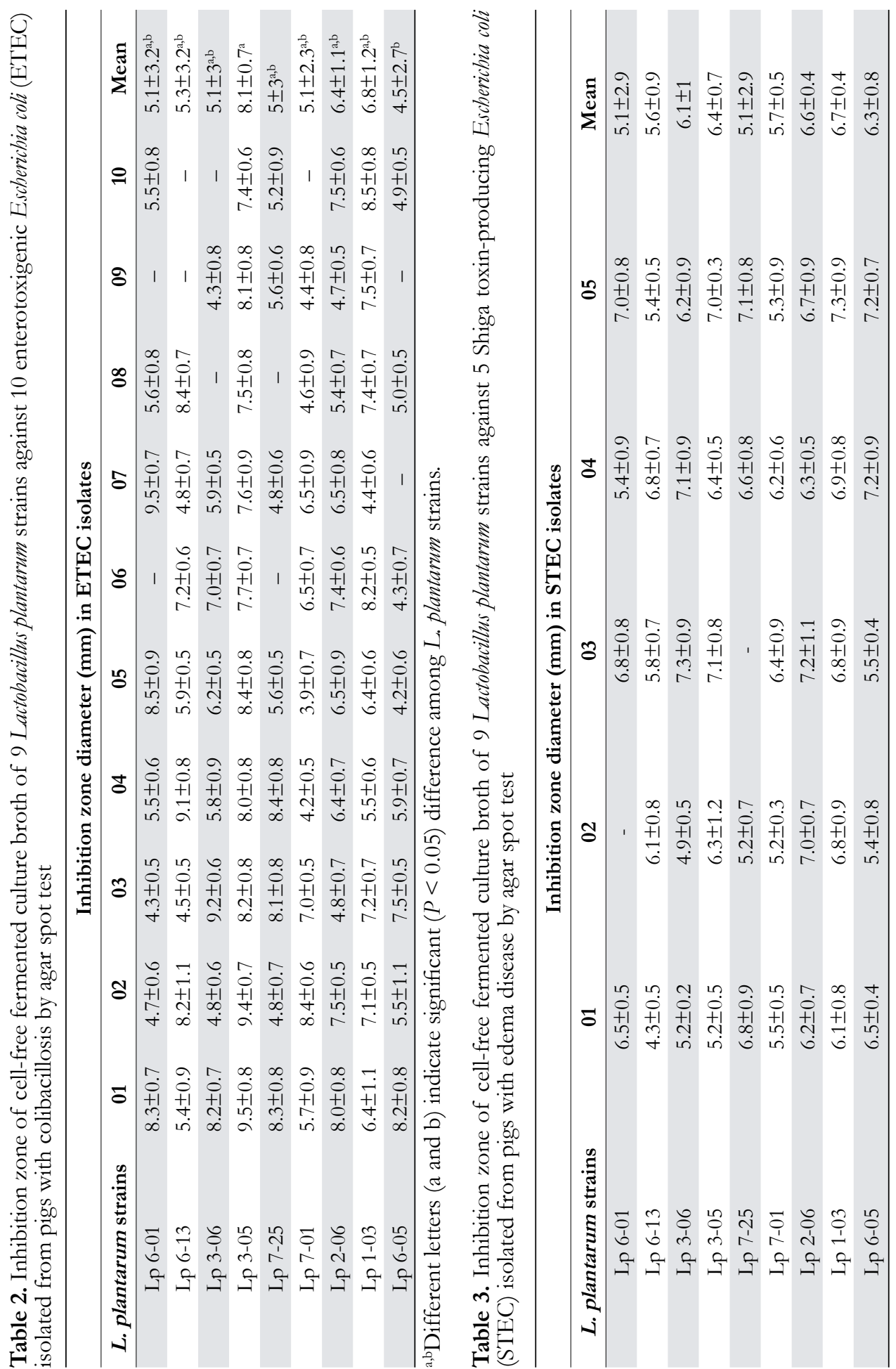




\section{CONCLUSION}

Among 9 L. plantarum strains tested, 3 strains (Lp 3-05, 2-06, and 1-03) showed inhibitory activity of in vitro growth against 10 ETEC (100\%) and 5 STEC (100\%) strains tested. These observations are clinically meaningful because outbreaks of colibacillosis and edema disease are rapidly increasing since the restriction of antibiotic feed additives was implemented by the government. L. plantarum strains are promising probiotics to control colibacillosis and edema disease in postweaning pigs.

\section{Acknowledgments}

This study was supported by the Bio-Industry Technology Development Program (Grant no. 312059-03), Ministry of Agriculture, Food and Rural Affairs, Republic of Korea. The research was also supported by Brain Korea 21 PLUS Program for Veterinary Science and contract research funds of the Research Institute for Veterinary Science from the College of Veterinary Medicine in Seoul National University, Republic of Korea.

\section{REFERENCES}

1. Fairbrother JM, Gyles CL: Colibacillosis. In: Diseases of Swine. United Kingdom: Blackwell Publishing; 2012, 723-749.

2. Marques LRM, Peiris JSM, Cryz SJ, O'Brien AD: Escherichia coli strains isolated from pigs with edema disease produce a variant of Shiga-like toxin II. FEMS Microbiol Lett 1987, 44: 33-38.

3. Imberechts H, de Greve H, Schlicker C, Bouchet H, Pohl P, Charlier G, Bertschinger H, Wild P, Vandekerckove J, van Damme J, van Montagu M, Lintermans P: Characterization of F107 fimbriae of Escherichia coli 107/86, which cause edema disease in pigs, and nucleotides sequence of the F107 major fimbrial subunit gene, fedA. Infect Immun 1992, 60: 1963 1971.

4. MacLeod DL, Gyles CL, Wilcock BP: Reproduction of edema disease of swine with purified Shiga-like toxin-II variant. Vet Pathol 1991, 28: 66-73.

5. Kwon D, Choi C, Jung T, Chung H-K, Kim J-P, Bae S-S, Cho W-S, Kim J, Chae C: Genotypic prevalence of the fimbrial adhesions (F4, F5, F6, F41 and F18) and toxins (LT, $\mathrm{STa}, \mathrm{STb}$ and Stx2e) in Escherichia coli isolated from postweaning pigs with diarrhoea or oedema disease in Korea. Vet Rec 2002, 150: 35-37.

6. Uemura R, Sueyoshi M, Nagayoshi M, Nagatomo H: Antimicrobial susceptibilities of Shiga toxin-producing Escherichia coli isolates from pigs with edema disease in Japan. Microbiol Immunol 2003, 47: 57-61.

7. Yang H, Chen S, White DG, Zhao S, McDermott P, Walker R, Meng J: Characterization of multiple-antimicrobial-resistance Escherichia coli isolates from diseased chickens and swine in China. J Clin Microbiol 2004, 42: 3483-3489.

8. Wierup M: The control of microbial diseases in animals: alternative to the use of antibiotics. Int J Antimicrob Agents 2000, 14: 315-319. 
9. Reid G, Friendship R: Alternatives to antibiotic use: probiotics for the gut. Anim Biotechnol 2002, 13: 97-112.

10. Seyda C, Gökçen D, Mehtap Ünlü S: Detection of several virulence properties, antibiotics resistance and phylogenetic relationship in E. coli isolated originated from cow mastitis. Acta Vet-Beograd 2014, 64:413-425.

11. Kwon, D, Kim O, Chae C: Prevalence of genotypes for fimbriae and enterotoxins and of O serogroups in Escherichia coli isolated from diarrheic piglets in Korea. J Vet Diagn Invest 1999, 11: 146-151.

12. Tagg JR, Dajani AS, Wannamaker LW: Bacteriocins of Gram-positive bacteria. Bacteriol Rev 1967, 40: 722-756.

13. Fooks LJ, Gibson GR: In vitro investigation of the effect of probiotics and prebiotics on selected human intestinal pathogens. FEMS Microbiol Ecol, 2002, 39: 67-75.

14. Katarína K, Peter R, Herbert S, Martina B, Balász K: Influence of beta-glucan and vaccination against Lawsonia intracellularis on selected immune indices in weaned piglets. Acta Vet-Beograd 2014, 64:105-114.

15. Servin AL: Antagonistic activities of lactobacilli and bifidobacteria against microbial pathogens. FEMS Microbiol Rev 2004, 2: 405-440.

\title{
INHIBICIJA IN VITRO RASTA ENTEREROTOKSIČNE I ŠIGA TOKSIN PRODUKUJUĆE E. COLI POMOĆU LACTOBACILLUS PLANTARUMSOJEVA KOD PRASADI
}

\author{
CHANGHOON Park, JIWOON Jeong, KYUHYUNG Choi, JAE CHUL Lee, OH \\ SUNG Kwon, SUNG-HOON Kim, CHANHEE Chae
}

Cilj rada je bio procena fermentisanog rastvora 9 Lactobacillus plantarum sojeva kao alternativa antibioticima za inhibiciju in vitro rasta enterotoksične E. coli (ETEC) i sojeva E. coli koji proizvode šiga toksin (STEC) izolovane kod prasadi sa kolibacilozom ili edemskom bolešću nakon zalučenja tokom 2014. godine. Antimikrobna osetljivost je testirana na ukupno 10 ETEC i 5 STEC sojeva izolovanih kod prasadi nakon zalučenja. ETEC i STEC sojevi koji su korišćeni u ovoj studiji posedovali su barem jedan od fimbrijalnih, enterotoksičnih i šiga toksin gena ustanovljenih PCR metodom. Od 9 L. plantarum testiranih sojeva 3 soja (Lp 2-05, 2-06, and 1-03) su imala inhibitornu aktivnost na in vitro rast 10 ETEC sojeva (100\%), dok je 7 sojeva (Lp 6-13, 3-06, 3-05, 7-01, 2-06, 1-03, and 6-05) pokazalo in vitro inhibitornu aktivnost rasta 5 STEC sojeva (100\%). Tri soja (Lp 3-05, 2-06, and 1-03)je in vitro pokazalo inhibitornu aktovnost na rast 10 ETEC (100\%) i 5 STEC (100\%) soja. Rezultati ove studije ukazuju na inhibitornu aktivnost fermentisanog hranjlivog medijum L. plantarum na rast ETEC i STEC izolovanih kod zalučene prasadi sa kolibacilozom i edemskom bolešću. 